\title{
ANALISIS KADAR BETA KAROTEN DAN VITAMIN C BUAH JUWET (Syzigium cumini) METODE SPEKTROFOTOMETRI UV-VIS
}

\author{
Panji Ratih Suci*, Nadya Hapsari, Reny Dwi \\ Akademi Farmasi Mitra Sehat Mandiri Sidoarjo \\ *: panjiratihsuci13@gmail.com
}

\begin{abstract}
ABSTRAK
Beta-carotene ( $\beta$-Karoten) merupakan senyawa organik dan diklasifikasikan sebagai suatu terpenoid. $\beta$-Karoten adalah pigmen berwarna merah-orange yang sangat berlimpah pada tanaman dan buah-buahan. Beta-karoten diperkirakan memiliki banyak fungsi yang tidak dimiliki senyawa lain (Subawati, 2009).Tujuan penelitian ini adalah untuk menentukan kadar $\beta$-Karoten Pada Buah Juwet (Syzygium Cumini) secara spektrofotometri UV-Vis. Sampel Buah Juwet (Syzygium Cumini) diekstraksi dengan pelarut aseton. Ekstrak yang diperoleh diekstraksi kembali dengan pelarut petroleum eter, kemudian disaponifikasi dengan pelarut $\mathrm{KOH} 15 \%$ dalam metanol. Ekstrak tersebut dibebas basakan dengan air suling. Ekstrak yang diperoleh dikeringkan dengan Na2SO4 anhidrat. Ekstrak yang diperoleh dianalisis kualitatif dengan menggunakan Kromatografi Lapis Tipis, dan spektrofotometri UV-Vis pada panjang gelombang 332,1539 nm diperoleh kadar rata-rata $\beta$-karotenpada buah juwet $1,25 \mathrm{mg}$. Analisis kadar Vitamin $\mathrm{C}$ dilakukan Pada panjang gelombang 265,3 nm diperoleh kadar rata rata Vitamin $\mathrm{C}$ pada buah juwet 1,473 mg.
\end{abstract}

Kata Kunci: Beta-Karoten, Vitamin C, Spektrofotometri UV-Vis

\begin{abstract}
Beta-carotene ( $\beta$-Carotene) is an organic compound and is classified as a terpenoid. $\beta$-Carotene is a red-orange pigment that is very abundant in plants and fruits. Beta-carotene is thought to have many functions that other compounds do not have (Subawati, 2009). The aim of this study was to determine $\beta$-carotene levels in juwet fruit (Syzygium Cumini) by UV-Vis spectrophotometry. Juwet fruit samples (Syzygium Cumini) were extracted with acetone as a solvent. The extract obtained was extracted again with petroleum ether solvent, then saponified with $15 \% \mathrm{KOH}$ solvent in methanol. The extract was liberated with distilled water. The extract obtained was dried over anhydrous Na2SO4. The extract obtained was analyzed qualitatively using Thin Layer Chromatography, and UV-Vis spectrophotometry at a wavelength of $332.1539 \mathrm{~nm}$. The average level of $\beta$-carotene in juwet fruit was $1.25 \mathrm{mg}$. Analysis of Vitamin C levels was carried out at a wavelength of $265.3 \mathrm{~nm}$, the average level of Vitamin $C$ in juwet fruit was 1.473

Keywords: Beta-Carotene, Vitamin C, UV-Vis Spectrophotometry
\end{abstract}




\section{PENDAHULUAN}

Indonesia merupakan wilayah yang beriklim tropis dan berada di daerah khatulistiwa. Indonesia memungkinkan tumbuhnya berbagai macam tumbuh-tumbuhan dengan subur seperti buah-buahan (Putri \& setiawati, 2015).

\section{Beta-carotene $\quad(\beta$-Karoten $)$} merupakan senyawa organik dan diklasifikasikan sebagai suatu terpenoid. $\beta$-Karoten adalah pigmen berwarna merah-orange yang sangat berlimpah pada tanaman dan buahbuahan. Beta-karoten diperkirakan memiliki banyak fungsi yang tidak dimiliki senyawa lain. Jumlah yang dibutuhkan tubuh memang hanya ukuran milligram perhari. Tapi kalau tidak terpenuhi dapat menimbulkan gangguan fungsi (Subawati, 2009).

Vitamin $\mathrm{C}$ adalah vitamin yang terlarut dalam air dan memiliki peranan penting dalam menangkal berbagai penyakit. Vitamin $\mathrm{C}$ juga dikenal dengan nama lain yaitu asam askorbat, asam L-xiloaskorbat, 3ono-gulofuranolanton serta vitamin anti sorbutat. Vitamin yang mudah mengalami oksidasi. Vitamin C adalah vitamin yang paling mudah rusak dalam bentuk cair (Mardalena,2017). Salah satu manfaat mengosumsi vitamin $\mathrm{C}$ adalah dapat memberikan efek terbaik untuk menurunkan pravelansi anemia baik pada anak-anak maupun orang dewasa. Hasil penelitian oleh Saidin \& Sukati (1997) membuktikan bahwa pemberian Vitamin $\mathrm{C}$ dapat meningkatkan kadar hemoglobin tertinggi. Vitamin $\mathrm{C}$ juga berperan untuk pembentukan kolagen yang bermanfaat untuk penyembuhan luka. Ketersediaan Vitamin C yang cukup dalam darah dapat mendorong kerja selenium dalam menghambat sel kanker, terutama kanker paruparu, prostat, payudara, usus besar, empedu, dan otak.

Tanaman juwet merupakan tanaman yang kaya akan manfaat. Semua bagian organ dari tanaman juwet dapat digunakan sebagai tanaman obat dalam pengobatan alternatif (Reynetron et al., 2005). Organ-organ tanaman tersebut memiliki senyawa metabolit sekunder yang berbeda-beda pada setiap organ.

Salah satu organ tanaman juwet yang dapat dimanfaatkan sebagai 
obat adalah organ buahnya. untuk menemukan serta mengetahui Pemanfaatan dari buah juwet ini kadar beta karoten dan Vitamin C digunakan sebagai antioksidan dari buah Juwet tersebut.

(Rekha et al., 2012). Hal ini dikarenakan buah juwet mengandung asam malat dan sejumlah kecil asam oksalat, asam galat, tanin, antosianin, flavanoid, glukosa, fruktosa, mannose, dan galaktosa. Mineral yang terkandung dalam buah juwet meliputi $\mathrm{Ca}, \mathrm{Mg}, \mathrm{Na}, \mathrm{K}, \mathrm{Cu}$ dan vitamin seperti tiamin, riboflavin, asam nikotinat. Syzygium cumini dimanfaatkan sebagai sumber buah dan obat tradisional, namun pemanfaatannya sebagai obat lebih banyak diteliti. Pemanfaatan $S$. cumini sebagai obat telah tercatat dalam naskah pengobatan tradisional India di dalam Dalam pengobatan tradisional S. cumini dimanfaatkan untuk mengatasi penyakit keputihan, gangguan lambung, demam, diabetes, sakit perut, luka, dan gigi, gangguan pencernaan, dan kulit (Jagetia 2017).

Hasil penelitian telah membuktikan manfaat S. cumini sebagai anti diabetes mellitus Berdasarkan hal tersebut, maka perlu dilakukan penelitian kandungan karoten dan Vitamin C dari buah Juwet S.Cumini

\section{METODE PENELITIAN}

Alat yang digunakan dalam penelitian ini antara lain corong pisah, corong, gelas ukur, labu tentukur, labu erlenmeyer, neraca analitik, Kertas saring, Beaker glass perangkat alat kromatografi lapis tipis, perangkat alat soxhlet, spektrofotometer ultraviolet-visibel.

Bahan yang digunakan adalah aquadest, aseton, $\beta$-karoten, Vitamin $\mathrm{C}$, natrium sulfat anhidrat, metanol, kalium hidrok-sida, petroleum eter, Buah Juwet.

\section{PENGOLAHAN SAMPEL}

\section{a. BETA-KAROTEN}

Buah Juwet di cuci bersih lalu pisahkan buah dengan bijinya, kemudian dipotong-potong kecil. Timbang 50 gram , masukkan dalam labu soxhlet dan diekstraksi dengan $100 \mathrm{ml}$ aseton. Ekstrak aseton yang diperoleh dikisatkan kurang lebih sebanyak $5 \mathrm{ml}$, kemudian hasilnya diekstraksi kembali dengan petroleum eter sebanyak $25 \mathrm{ml}$. Kemudian dilakukan saponifikasi 
dengan larutan $\mathrm{KOH} 15 \%$ dalam metanol. Hasil saponifikasi diekstraksi dengan petroleum eter sebanyak $25 \mathrm{ml}$, lalu dicuci dengan air suling sampai bebas basa, lalu dikeringdengan $\mathrm{Na} 2 \mathrm{SO} 4$ anhidrat dan disaring.

\section{b. VITAMIN C}

Buah Juwet di cuci bersih lalu pisahkan buah dengan bijinya kemudian gerus hingga homogen saring menggunakan kertas saring dan diambil perasaannya, sebanyak 5 gram untuk setiap perlakuan. Masukkan ke dalam erlenmeyer $50 \mathrm{ml}$ yang sudah dikalibrasi, tambahkan aquadest sampai tanda batas, tutup dengan aluminium foil digojog hingga homogen. Saring untuk memisahkan ampasnya, ambil $1 \mathrm{ml}$ sampel dimasukkan dalam labu ukur $50 \mathrm{ml}$ tambahkan aquadest sampai tanda batas, kocok sampai homogen. Baca absorbansinya pada spektrofotometri UV-Vis dan hitung kadar Vitamin C dalam sampel.

\section{c. ANALISIS KADAR BETA KAROTEN}

Pembanding Beta-Karoten

murni dan ekstrak sampel yang telah diencerkan dengan Etanol, ditotolkan bersama-sama pada lempeng KLT dengan cairan pengelusi Heksana : Aseton : Etanol (1:1:4). Noda yang dihasilkan diamati dengan penampak noda sinar UV.

Sebanyak 25 mg Beta-karoten murni yang ditimbang teliti dilarutkan dalam $30 \mathrm{ml}$ Etanol di dalam labu terukur $50 \mathrm{ml}$ lalu dicukupkan volumenya hingga 50 $\mathrm{ml}$, sehingga diperoleh larutan stok dengan konsentrasi 500 ppm. Dari larutan tersebut dipipet masingmasing berturut-turut sebanyak 0,6 $\mathrm{ml}, 0,7 \mathrm{ml}, 0,8 \mathrm{ml}, 0,9 \mathrm{ml}, 1 \mathrm{ml}, 0,44$ $\mathrm{ml}, 0,48 \mathrm{ml}, 0,52 \mathrm{ml}, 0,56 \mathrm{ml}$ dan 0,6 $\mathrm{ml}$ dimasukkan ke dalam labu terukur dan volume dicukupkan hingga $25 \mathrm{ml}$ dan $10 \mathrm{ml}$ diperoleh seri larutan baku dengan konsentrasi 12 ppm, 14 ppm, 16 ppm, 18 ppm, 20 ppm, 22 ppm, 24 ppm, 26 ppm, 28 ppm 30 ppm. Salah satu dari seri konsentrasi bahan baku beta-karoten diukur serapannya dengan spektrofotometer pada beberapa panjang gelombang untuk menentukan panjang gelombang serapan maksimum. Selanjutnya 
seri larutan baku dengan konsentrasi sampel 12 ppm, 20 ppm, 30 ppm diukur serapannya pada panjang gelombang serapan maksimum. Sampel yang telah disiapkan diukur pula serapannya dengan spektrofotometer pada panjang gelombang maksimum $450 \mathrm{~nm}$.

2. ANALISIS KADAR VITAMIN C

\section{a. UJI WARNA}

Melakukan Penimbangan Vitamin C sebanyak $50 \mathrm{mg}$ dalam 50 ml aquadest kemudian masukkan 15 tetes larutan Vitamin C ke dalam tabung reaksi lalu tambahkan 15 tetes reagen benedict. Perhatikan perubahan warna yang terjadi dan jika terdapat endapan warna hijau kekuningan sampai merah bata maka menunjukkan hasil positif.

Timbang perasan buah juwet yang sudah disaring $5 \mathrm{mg}$ dalam 50 $\mathrm{ml}$ aquadest. Masukkan 15 tetes perasan juwet ke dalam tabung reaksi lalu tambahkan 15 tetes reagen benedict. hasil positif ditunjukkan apabila terdapat endapan warna hijau kekuningan sampai merah bata.

Sebanyak $50 \mathrm{mg}$ Vitamin C yang ditimbang dilarutkan dalam $50 \mathrm{ml}$ aquadest dalam labu ukur $50 \mathrm{ml}$ lalu dicukupkan volumenya hingga $50 \mathrm{ml}$, sehingga diperoleh larutan dengan konsentrasi 1000 ppm. Dari larutan tersebut pipet mikro sebesar $0,1 \mathrm{ml}$; $0,2 \mathrm{ml} ; 0,3 \mathrm{ml} ; 0,4 \mathrm{ml} ; 0,5 \mathrm{ml} ; 0,6 \mathrm{ml}$; 0,7 ml di masukkan kedalam labu ukur $50 \mathrm{ml}$ dan di tambahkan aquadest sampai tanda batas, hingga di peroleh larutan dengan konsentrasi 2,0 ppm; 4,0 ppm; 6,0 ppm; 8,0 ppm; 10,0 ppm; 12,0 ppm; 14,0 ppm.

Salah satu dari seri konsentrasi bahan baku Vitamin $\mathrm{C}$ diukur serapannya dengan spektrofotometri pada beberapa panjang gelombang untuk menentukan panjang gelombang serapan maksimum. Selanjutnya seri larutan baku dengan konsentrasi sampel 2 ppm, 8 ppm, 14 ppm di ukur serapanya pada panjang gelombang serapan maksimum. Dari hasil penelitian penetapan kadar vitamin $\mathrm{C}$ pada buah juwet menunjukkan hasil yang linier. Penelitian dimulai dengan membuat larutan baku kerja 14 ppm untuk menentukan panjang gelombang vitamin C pada rentang 200-400 nm. Kadar vitamin C dapat diukur pada panjang gelombang UV $266 \mathrm{~nm}$ 
(Farmakope indonesia IV, 1995).

\section{HASIL DAN}

\section{PEMBAHASAN}

Pada penelitian ini telah dilakukan analisis untuk mengetahui kadar beta-karoten dan vitamin $\mathrm{C}$ pada buah juwet. Beta-carotene ( $\beta$ Karoten) merupakan senyawa organik dan diklasifikasikan sebagai suatu terpenoid. Manfaat betakaroten bagi tubuh adalah untuk mencegah dan menurunkan resiko kanker. Mengkonsumsi makanan atau buahbuahan yang mengandung betakaroten diharapkan bisa menunjang kebutuhan gizi dan meningkatkan kekebalan tubuh. Sifat antioksidan yang terdapat pada betakaroten dapat melindungi tumbuhan dan mikroorganisme dari sinar matahari yang merusak(Listya, 2010).

Pada penelitian ini sampel yang digunakan adalah buah juwet dengan tujuan untuk mengetahui kadar betakaroten dan Vitamin C yang terkandung dalam buah juwet.

Pada analisis kualitatif, ekstrak petroleum eter buah juwet diuji dengan Kromatografi Lapis Tipis (KLT) dengan pembanding $\beta$-karoten murni, menggunakan cairan pengelusi N. Heksana : Aseton : Etanol (1 : $1: 4)$. Dan diperoleh bercak ungu pada buah juwet dengan nilai Rf 0,91 dan pada beta-karoten murni dengan nilai 0,93 . Hal ini menunjukkan bahwa sampel buah juwet mengandung senyawa betakaroten.

Berdasarkan hasil uji warna berdasarkan penambahan pereaksi benedict menunjukkan bercak merah hal tersebut menunjukkan reaksi positif (+) mengandung vitamin $\mathrm{C}$ pada buah juwet. Hasil menunjukkan sangat sedikit yang terkandung vitamin C pada buah juwet, dikarenakan terlalu lama penyimpanan dikulkas mengakibatkan kadar yang keluar hanya sangat sedikit. Setelah diuji menggunakan KLT dan Uji warna di lanjutkan dengan mengetahui kadar Beta-karoten dan vitamin C pada buah juwet.. 
Tabel 1. Hasil kurva baku serapan $\beta$-karoten pada buah juwet (Syzygium Cumini).

\begin{tabular}{ccc}
\hline No & Konsentrasi $(\mathbf{x})$ & Abs $(\mathbf{y})$ \\
\hline $\mathbf{1 .}$ & 12 & 0,2710 \\
\hline $\mathbf{2 .}$ & 14 & 0,3232 \\
\hline $\mathbf{3 .}$ & 16 & 0,3681 \\
\hline $\mathbf{4 .}$ & 18 & 0,4058 \\
\hline $\mathbf{5 .}$ & 20 & 0,4468 \\
\hline $\mathbf{6 .}$ & 22 & 0,4608 \\
\hline $\mathbf{7 .}$ & 24 & 0,5464 \\
\hline $\mathbf{8 .}$ & 26 & 0,5828 \\
\hline $\mathbf{9 .}$ & 28 & 0,6262 \\
\hline $\mathbf{1 0}$ & 30 & 0,6767
\end{tabular}

Tabel 2. Hasil kurva baku serapan Vitamin $\mathrm{C}$ pada buah juwet (Syzygium Cumini)

\begin{tabular}{ccc}
$\begin{array}{c}\text { No } \\
\text { Standart }\end{array}$ & $\begin{array}{c}\text { Konsentrasi } \\
(\mathbf{p p m})\end{array}$ & $\begin{array}{c}\text { Absorbansi } \\
\text { (ABS) }\end{array}$ \\
\hline $\mathbf{1}$ & 2 & 0,1269 \\
\hline $\mathbf{2}$ & 4 & 0,2194 \\
\hline $\mathbf{3}$ & 6 & 0,3447 \\
\hline $\mathbf{4}$ & 8 & 0,4299 \\
\hline $\mathbf{5}$ & 10 & 0,5270 \\
\hline $\mathbf{6}$ & 12 & 0,6162 \\
\hline $\mathbf{7}$ & 14 & 0,7291 \\
\hline
\end{tabular}

\section{KESIMPULAN}

Berdasarkan data hasil penelitian yang telah dilakukan, kadar Beta- Karoten dan Vitamin C pada buah juwet secara spektrofotometri UV-VIS berturutturut sebesar 1,25 mg dan 1,74 mg. Pada analisis kuantitatif digunakan alat spektrofotometri UV-Vis dan diperoleh kadar beta-karoten dengan rata - rata $1,25 \mathrm{mg}$ dan kadar vitamin $\mathrm{C}$ dengan rata - rata 1,743 .

Hasil kadar Beta-Karoten dan Vitamin C yang sangat sedikit, Karena penyimpanan buah juwet yang sudah terlalu lama dan membuat buah tidak segar lagi, menjadikan penelitian ini dengan hasil yang tidak maksimal. 


\section{UCAPAN TERIMAKASIH}

Terima kasih kepada Akademi

Farmasi Mitra Sehat Mandiri

Sidoarjo yang telah memberikan dukungan penuh, sehingga penelitian ini dapat dilaksanakaan dengan lancar.

\section{DAFTAR PUSTAKA}

1. Ayyanar Muniappan, 2012, Syzygium cumini (L.) Skeels: A review of itsphytochemical constituentsand traditional uses, Asian Pacific Journal of Tropical Biomedicine, 240246.

2. Dalimarta, S, 2003, Atlas Tumbuhan Obat Indonesia Jilid 3, Puspa Swara, Jakarta, hal. 19-23.

3. Jagetia, G.C. (2017). Phytochemical Composition and pleotropic pharmacological properties of jamun, Syzygium cumini skeels. ournal of Exploratory Research in Pharmacology 2: 54-66.

4. Antioksidan Dari buah Melon (Cucumis melo Linn.) Secara Spektrofotometri UV-Vis. Skripsi Fakultas Ilmu Kesehatan Universitas Islam Negeri Alauddin Makassar.

5. Mardalena, Ida. 2017. Dasardasar Ilmu Gizi Dalam Keperawatan. Yogyakarta: Pustaka Baru Press

6. Putri, M.P, Setyawati, Y.H, 2015, Analisis Kadar Vitamin C Pada Buah Nanas Segar
(Annas comosus (L.) Merr) dan buah Nanas Kaleng Dengan Metode Spektrofotometri UVVis, Jurnal Wiyata; (34)

7. Rekha C, Poornima G, Manasa M, Abhipsa V, Devi JP, Kumar HTV, Kekuda TRP. 2012.Ascorbic acid, total phenol content and antioxidant activity of fresh juice of four ripe and unripe citrus fruits. Research Article. Chemical Science Transactions. 1(2): 303-310

8. Reynetron, K.A, Basile M.J, Kennelly E.J. 2005. Antioxidant Potential of Seven Myrtaceous Fruits. Ethnobot Res Ap. 3:25 -35

9. Saidin,M. dan Sukati S., 1997, Pengaruh Pemberian Pil Besi Dengan Penambahan Vitamin Terhadap Perubahan kadar HB dan Feritin Serum Pada Wanita Remaja, The Joural of Nutrition and Food Research (Jilid 20;92-100)

10. Subawati,Reni, 2009, Oksidasi Senyawa Karoten Dalam Buah Kelapa Sawit,Universitas Ma Chung. Malang 